\title{
SOCIO-PHILOSOPHICAL ANALYSIS OF CULTURE DEVELOPMENT: METHODOLOGICAL ASPECTS OF FOLK ART RESEARCH
}

\author{
(C) Marina V. Makhrinova, Vyacheslav A. Berkovsky, Ekaterina Yu. Litvinova
}

\author{
North-Caucasus Federal University, Stavropol State Pedagogical Institute \\ Stavropol, Russian Federation \\ science-almanac@mail.ru
}

One of the most important topics related to the development of culture, its traditions and its role in modern life is folk art. Folk art as a part of culture is a rich complex of many phenomena, which together make up the essence of the concept, folk tradition, phenomena that are especially noticeable in the cultural heritage of the people in their entertainment. This applies to folk art, both traditional and modern. The latter, for the most part, rooted deep in history, still bears a living trace of the past and thus is a form of a revived tradition. The connection with the past and continuity are manifested in folk art much more strongly than in any other area of folk culture. This feature of folk art in the period of progressive universalization of culture determines its role in the development of modern national culture. The stability of the phenomenon of artistic folk art, as well as its vitality both in material embodiment and in various socio-economic and cultural-ideological manifestations, is of fundamental importance.

Key words: cultural values, cultural heritage, public consciousness, national culture, religious cult, aesthetic needs, state.

[М.В. Махринова, В.А. Берковский, Е.Ю. Литвинова Социально-философский анализ развития культуры: методологические аспекты исследования народного искусства]

Из множества тем, связанных с проблемой развития культуры, ее традиций и ее роли в современной жизни актуальными являются темы, относящиеся к народному искусству. Народное искусство как часть культуры представляет собой богатый комплекс многих явлений, составляющих в совокупности сущность понятия, народная традиция, явлений, по своей зрелищности особенно заметных в культурном наследии народа. Это касается народного искусства как традиционного, так и современного. Последнее в большинстве своем корнями уходящее вглубь истории, носит еще живой след прошлого и тем самым является формой ожившей традиции. Связь с прошлым и преемственность проявляются в народном искусстве значительно сильнее, чем в какой-либо другой области народной культуры. Эта особенность народного искусства в период прогрессирующей универсализации культуры определяет его роль в развитии современной национальной культуры. Основное значение имеет устойчивость феномена художественного народного творчества, а также его жизненность как в материальном воплощении, так и в разных общественно-экономических и культурно-идеологических проявлениях.

Ключевые слова: культурные ценности, культурное наследие, общественное сознание, национальная культура, религиозный культ, эстетические потребности, государство.

Marina V. Makhrinova - Ph.D. in Pedagogy, Associate Professor, North-Caucasus Federal University, Stavropol, Russian Federation.

Vyacheslav A. Berkovsky - Ph.D. in Sociology, Associate Professor, Stavropol State Pedagogical Institute, Stavropol, Russian Federation.

Ekaterina Yu. Litvinova - Ph.D. in Pedagogy, North-Caucasus Federal University, Stavropol, Russian Federation.

Махринова Марина Владимировна - кандидат педагогических наук, доцент, Северо-Кавказский федеральный университет, г. Ставрополь, Российская Федерация.

Берковский Вячеслав Александрович - кандидат социологических наук, доцент, Ставропольский государственный педагогический институт, г. Ставрополь, Российская Федерация.

Литвинова Екатерина Юрьевна - кандидат педагогических наук, Северо-Кавказский федеральный университет, г. Ставрополь, Российская Федерация. 
The policy of "war communism" began to take shape in Russia already during the civil war of the $20^{\text {th }}$ century. Its economic inefficiency, scientific lack of thought and complete failure forced for a certain period to interrupt this peculiar method of management and make a transition to a new economic policy, which contributed to the maximum use of the economic incentives of the Soviet transformation period. As a rule, the agrarian-industrial transformation corresponds to a free market, especially in agriculture, but this was not typical for Russia; attempts at market reforms in the agrarian sector were thwarted for the first time by the revolution of 1917, and the second time after the curtailment of the New Economic Policy (NEP). Peasant resourcefulness, enterprise, skills were practically not used here.

Already in the XIX century there was a great interest in folk art as a source of original culture and an expression of artistic possibilities of the people. This was particularly evident during the Romanticism and Neo-Romanticism period, together with an interest in the economic aspects of folk art through an activist approach, which defines "... human quality and the resulting ability of social actors to interact purposefully with the environment" [14, p. 282284], "the complex interaction of different types of social communication" [2, p. 5-10].

In the twentieth century, the importance of folk art was increased by the awareness of its class character, which gave it the rank of an exponent of artistic creation of the peasants in the field of culture. At the same time, folk art, which was widely recognized, had a tremendous opportunity to assume the role of a link between the culture of peasants and other social strata. As folk art was discovered as a cultural value, it began not only to serve its environment, but also to be perc-eived by other social circles, which adapted its various forms and variants.

After the Second World War, with the formation of a new social and cultural reality, folk art, deemed equal to academic art, was a special ward of the state and included in its cultural activities. The assessment of the role and significance of tradition and folk art in public life and culture, as well as the notion of their nature and essence, were not unified throughout the post-war period. Disputes about their ideological content naturally increased during some tense social situations and were dependent on the differences in views on the significance of the entire cultural heritage.

The first post-war years are characterized by the search for concepts and models of national culture and national art, created with the participation of folk culture. These concepts clearly show an appeal to the legacy of peasant doctrines of the interwar period. It was the time of struggle for the position of the peasant in the country social structure. These concepts contributed to the development of self-awareness and social consciousness while making connections with the values of folk culture. According to these concepts, the concept of folk tradition encompassed those elements of culture that, having received recognition in the peasant environment, created a certain internal organization of its complexes. These elements were introduced into the national culture as a legacy of the peasant class, which took its own position as a result of the social revolution, one of the directions of these programs of action was to create art for the masses, thereby defining the national character. National character can be learned by studying the national upbringing system [4, p. 28-34]. It is necessary to organize a system of upbringing and education based on scientific research of forms, methods, directions and mechanisms of personality development [13, p. 15-18]. Dialogue and interaction of cultures ensures "... promotion of a positive attitude towards cultural differences" [5, p. 7-10]. "The functioning of different cultures have common principles" [7, p. 3-9]. "Culture is understood as the inner essence of human ideas..." [3, p. 3-9]. "Culture is an essential characteristic of the society social sphere, it is inseparable from human social activity" [9, p. 74-78], in one way or another, it determines the socio-cultural development of society $[10$, p. 123-128]. 
Folk art in the concepts of this period was considered the heritage of the peasant strata culture and contributed to the development of patriotism, expanding its contribution to the national culture. At the same time, during this period another trend was emerging which would later determine the development of folk art, exhibiting the unity of urban and rural working masses culture and considering only that part of the rural cultural heritage which was associated, first and foremost, with the class struggle. This is the period of the so-called biased art, programmatically involved in the restructuring of the country. This was reflected in the approach to the cultural heritage of the village, with folk traditions being understood only as those that were a reflection of the class struggle and in which progressive and revolutionary ideas were encapsulated. In accordance with the basic provisions of realism and the obligatory ideological content, folk art reflected the current cultural reality, fulfilling an educational and propaganda role. In terms of universality of perception and accessibility, folk art was mainly visual, true to realities when displaying the surrounding world. Its creators sought to find forms of expressive impact of their art, capable of having an educational impact on society by promoting certain ideas.

The new period, which began in the late 1950s and has continued to the present day, is a period when folk culture and art were well integrated into the national culture, the activities of the state administration of folk and art crafts, and the development of regional movements and other institutionalized forms. Proclaiming the relationship of art to society and endorsing its practical role was not enough. Folk art has regained its place in the national culture as a peculiar expression of peasant life, as an art still alive, despite the changes taking place in its social function. It is considered to be an artistic value, a national cultural heritage, a symbol of traditions and national identity. Unlike the previous period, when theory and postulates prevailed, it is characterized by practical activity.

The State Administration of Folk and Artistic Crafts was established at a time when folk art was on the wane. However, almost all over the country one could still find living traditions of handicrafts. The state has set itself the task of revitalizing various fields of folk art and traditional handicrafts organizing the demand for them from urban consumers. It changes not only approaches, but also, depending on the economic and cultural situation in the country, contributes to the acquisition of more experience, uses improved methods of work. Own workshop for the development of models was created, which provided invaluable services for the restoration of already forgotten samples and crafts techniques. Exhibitions, expositions, fairs, folk festivals were organized. As a result of these activities, the state becomes the largest patron of folk art throughout the country. Items of folk art and handicraft, their number and diversity demonstrate, however, their heterogeneity. Authentic folk art, closely associated with long-standing traditional regional art, as well as works of folk artists are represented in insignificant numbers. The biggest part is taken by the handicrafts, which often take from folk art only form, color or related to it by origin. All of them, however, are based on folk art traditions and differ radically from mass factory production.

A special role in the field of folk art belongs also to the modern regional movement. Both the rich tradition of this movement and other factors, conditioned by the reality of social life of that period, contributed to the fact that folk art and folklore became the main fields, on which the revival of culture in some regions concentrated. Local departments of culture, institutions and public organizations on a large scale launched a campaign aimed at providing care, development and popularization of folk art and folklore, which aroused as much enthusiasm as criticism. The forms of mass dissemination of folk art and folklore were very diverse: they were their propaganda by the mass media, paying attention both to folk craftsmen and art collectives, all kinds of public events such as bazaars, fairs, festivals, trades, scientific and popular publications, brochures and advertisements. However, as the number of events dedicated to folk art increased, the quality and artistic level of the works presented at these events decreased significantly. The growing demand was unfortunately associated with 
commercial calculation and mass distribution of folk art works in the form of souvenirs (regional and national). Full of deep content and meaning words "folk art" began to express other values and have become a certain stereotype. At the same time, occupying the primary position in the cultural policy of the state, folk art, widely promoted and popularized, acquired representational features, began to serve as a kind of design and coloristic decoration, decorating the regional and national holidays. The ties between folk art and its environment were weakening. This is a peculiar metamorphosis of the former functions of folk art and a displacement of the sphere of its social impact. Of course, all this cannot happen without the above-mentioned consequences for folk art itself. Widespread and mass popularization created a special fashion for folk art; It also caused that echoes of folk art can be traced in many areas of culture. Works of folk craftsmen can be seen in the form of household items and decorative items. Characteristically, folk art does not seek promptings for innovative thinking; on the contrary, it is seen as a constant and unchangeable value. It is a form of appeal to old traditions that are still close to us, contributing to the realization of historical continuity. Historical continuity as the highest value is closely related to historical memory [12, p. 41-47], guarantees the proper level and quality of the resulting cultural product, which contributes to the "dialogue of cultures in the context of the development of modern civilization" [16, p. 145160], defining modern sociality [1, p. 168-177].

What is the actual situation and place of folk art in our modern culture? When comparing its current state with that of the recent past, the change in the place occupied by this art in our consciousness and culture is striking. Its range of impact, limited in the past, has now expanded considerably, but at the same time it has moved into the realm of popular culture. Woven into the rhythm of regional folklore events (festivals, fairs), folk art becomes a form of entertainment, decorations, souvenirs. It is present in many areas of modern daily life, but its absence is noticeable in serious music, carvings, graphics, and painting. Contemporary cultural processes have clearly moved folk art from the sphere of artistic phenomena into the sphere of mass culture, significantly changing its rank.

At the same time, owing to the penetration of popular art into mass culture and the growing demand for it, it is not in danger of disappearing, although it no longer draws sustenance from its source environment. This means that folk art performs a new social function in an environment completely different from the one it came out of. But thanks to this new environment, which embraced folk art and recognized its artistic value, it was raised to the high rank of art. The state patronage of folk art, expressed in various organizational forms, allows us to call it an art with the character of an institution, and to contrast it with noninstitutionalized artistic creation. This creativity satisfies aesthetic needs of a certain environment, as well as of a certain part of the population, which is not attracted to traditional folk art. Such art often uses traditional forms and techniques, but usually differs from traditional art in design, color and function. As part of this creativity are created oleographs, dolls, figurines made of plaster, iron gate ornaments, wooden ornaments, objects of religious worship, forming a religious consciousness, emphasizing the influence of theological and aesthetic ideas on the philosopher [11, p. 68], noting "the influence of Orthodoxy on the formation and formalization of Russian culture" [15, p. 39-44]. Despite the fact that it is related to the social environment and satisfies its aesthetic needs, experts hesitate to call it folk art, defining it as peripheral or the art of the popular culture decay period. They believe that the widespread distribution and appealing power of this art can be explained by the lack of accessibility of decorative arts objects. It should be remembered, however, that in the history of folk art there are numerous examples of late approval and recognition of folk art in the XX century of some types of creativity, the origin of which is often attributed to the XVIII century. It seems that some other types of non-instituted art can now enter the cultural circulation if they achieve a certain stability, expressed in the approval of several generations of consumers, and connoisseurs discover their artistic merits. 
How, in the light of these facts, is the attitude of its creators and bearers formed towards folk art, who, however, spontaneously ceased to participate in its further development, being included in certain frameworks of production not intended for their own environment? It may be noted that here we are dealing with two trends that define the future direction of folk art, with the proviso that its present state should be interpreted as a certain stage that does not predetermine its final fate. So, we are dealing, on the one hand, with new styles and fashions created within the peasant environment, which manifest both their own creative thought, and the adaptation of urban cultural patterns to their style; and, on the other hand, with the return by roundabout way through the city to the village of folk art created in its environment. In this latter case, the village, forming its attitude to its own creativity, is subordinated to a much greater extent than in the past to an opinion about it formulated outside the peasant environment. The previously mentioned promotion of folk art and folklore has a positive role to play in encouraging reflection and keeping this area of culture in the circle of general interest. Characteristically, the village sees it as an expression of regional rather than class distinction: the population of each region expresses its local cultural identity through folk art and folklore. In most cases, participation in the creation and consumption of folk art is formed differently for peasant populations who migrate to cities, for whom the degree of assimilation depends on how much value orientations have been lost. These attitudes are changing along with the process of assimilation in the urban environment, simultaneously with the growth of education. "The analysis of its functions contributes to the formation of people's consciousness and behavior" [6, p. 87-88].

Noting only some of the attitudes of rural society towards its own culture, it should be emphasized that they are crucial for the continued existence of folk art. They, in turn, are influenced by government policy and its attitude to folk art. "In a multiethnic state, the general principles of solving ethno-cultural problems are often set by a political formula expressing a common national-state idea, including the principles of ethnic integration" [8, p. 3-11].

\section{Лumepamypa}

1. Бакланова О.А., Бакланов И.С. Современная российская социальность в контексте социального конструкционизма // Вопросы социальной теории. 2015. Т.7. №1-2. С. 168-177.

2. Бакланова О.А., Бакланов И.С. Контуры типологического исследования социальности современного общества // Известия Саратовского университета. Новая серия. Серия: Философия. Психология. Педагогика. 2014. Т. 14. № 2-1. С. 5-10.

3. Берковский В.А., Тронина Л.А. Социально-исторический аспект взаимодействия этнической культуры и личности в контексте общественного развития // Научный альманах стран Причерноморья. 2019. №1(17). С. 3-9.

4. Говердовская Е.В. Социокультурные и этнологические особенности региона основа модернизации высшего образования на Северном Кавказе // Ученые записки университета им. П.Ф. Лесгафтта. 2007. №7. С. 28-34.

5. Говердовская E.B. Особенности проектирования образовательного пространства высшей школы в поликультурном регионе // Экономические и гуманитарные исследования регионов. 2014. № 4. С. 7-10.

6. Гончаров В.Н. Политическая информация в общественной системе // Гуманитарные и социально-экономические науки. 2011. № 3(58). С. 106-110.

7. Гончаров В.Н., Колосова О.Ю., Литвинова Е.Ю. Этнический аспект различных культур: принципы развития и функционирования // Science Almanac of Black Sea Region Countries. 2019. №4(20). C. 3-9. 
8. Гончаров В.Н., Колосова О.Ю., Волков А.А. Этнокультурный аспект развития личности в образовательном пространстве // Science Almanac of Black Sea Region Countries. 2020. №1(21). C. 3-11.

9. Ерохин А.М. Социально-фиилософские аспекты развития культурной сферы общества // Экономические и гуманитарные исследования регионов. 2016. № 1. С. 74-78.

10. Ерохин А.М. Научно-информационный аспект исследования социокультурного развития общества в области культуры и искусства // Экономические и гуманитарные исследования регионов. 2015. №2. С. 123-128.

11. Камалова О.Н. Эстетическое освоение действительности в контексте фрилософрских идей Шеллинга // Гуманитарные и социально-экономические науки. 2008. № 1 (38). С. 67-69.

12. Кулешин М.Г., Леонова Н.А., Немашкалов П.Г. Концептуальные основы социальной ответственности корпоративных структур: исторический аспект // Научный альманах стран Причерноморья. 2019. №1(17). С. 41-47.

13. Лобейко Ю.А. Социально-педагогический аспект активности личности в системе общественного развития // Экономические и гуманитарные исследования регионов. 2015. №1. С. 15-18.

14.Лобейко Ю.А. Социальная активность личности в обществе: социальнопедагогические аспекты фоормирования // European Social Science Journal. 2014. №7-2(46). C. 282-284.

15. Матяш Т.П., Несмеянов Е.Е. Православный тип культуры: идея и реальность // Гуманитарные и социально-экономические науки. 2015. № 3(82). С. 39-44.

16. Несмеянов E.E. «Цивилизация молодых»: идея и реальность // Гуманитарные и социальные науки. 2013. №6. С. 145-160.

\section{References}

1. Baklanova O.A., Baklanov I.S. Sovremennaya rossiyskaya sotsialnost v kontekste sotsialnogo konstruktsionizma [Modern Russian sociality in the context of social constructionism]. Voprosy sotsialnoy teorii. 2015. V. 7. No. 1-2. pp. 168-177 (In Russian).

2. Baklanova O.A., Baklanov I.S. Kontury tipologicheskogo issledovaniya sotsialnosti sovremennogo obshchestva [Contours of the typological study of the sociality of modern society]. Izvestiya Saratovskogo universiteta. Novaya seriya. Seriya: Filosofiya. Psikhologiya. Pedagogika. 2014. V. 14. No. 2-1. pp. 5-10 (In Russian).

3. Berkovskiy V.A., Tronina L.A. Sotsialno-istoricheskiy aspekt vzaimodeystviya etnicheskoy kultury i lichnosti v kontekste obshchestvennogo razvitiya [Socio-historical aspect of interaction between ethnic culture and personality in the context of social development]. Nauchnyy almanakh stran Prichernomorya. 2019. No. 1(17). pp. 3-9.

4. Goverdovskaya Ye.V. Sotsiokulturnyye i etnologicheskiye osobennosti regiona osnova modernizatsii vysshego obrazovaniya na Severnom Kavkaze [Socio-cultural and ethnological features of the region - the basis for the modernization of higher education in the North Caucasus]. Uchenyye zapiski universiteta im. P.F. Lesgafta. 2007. No. 7. pp. 28-34 (In Russian).

5. Goverdovskaya Ye.V. Osobennosti proyektirovaniya obrazovatelnogo prostranstva vysshey shkoly $v$ polikulturnom regione [Features of the design of the educational space of a higher school in a multicultural region]. Ekonomicheskiye i gumanitarnyye issledovaniya regionov. 2014. No. 4. pp. 7-10 (In Russian). 
6. Goncharov V.N. Politicheskaya informatsiya v obshchestvennoy sisteme [Political information in the social system]. Gumanitarnyye i sotsialno-ekonomicheskiye nauki. 2011. No. 3(58). pp. 106-110 (In Russian).

7. Goncharov V.N., Kolosova O.Yu., Litvinova Ye.Yu. Etnicheskiy aspekt razlichnykh kultur: printsipy razvitiya i funktsionirovaniya [Ethnic aspect of different cultures: principles of development and functioning]. Science Almanac of Black Sea Region Countries. 2019. No. 4(20). pp. 3-9.

8. Goncharov V.N., Kolosova O.YU., Volkov A.A. Etnokulturnyy aspekt razvitiya lichnosti $\checkmark$ obrazovatelnom prostranstve [Ethnocultural aspect of personality development in the educational space]. Science Almanac of Black Sea Region Countries. 2020. No. 1(21). pp. 3-11.

9. Yerokhin A.M. Sotsialno-filosofskiye aspekty razvitiya kulturnoy sfery obshchestva [Socio-philosophical aspects of the development of the cultural sphere of society]. Ekonomicheskiye i gumanitarnyye issledovaniya regionov. 2016. No. 1. pp. 74-78 (In Russian).

10. Yerokhin A.M. Nauchno-informatsionnyy aspekt issledovaniya sotsiokulturnogo razvitiya obshchestva $v$ oblasti kultury $\mathrm{i}$ iskusstva [Scientific and informational aspect of the study of socio-cultural development of society in the field of culture and art]. Ekonomicheskiye i gumanitarnyye issledovaniya regionov. 2015. No. 2. pp. 123-128.

11. Kamalova O.N. Esteticheskoye osvoyeniye deystvitel'nosti v kontekste filosof-skikh idey Shellinga [Aesthetic mastering of reality in the context of Schelling's philosophical ideas]. Gumanitarnyye i sotsialno-ekonomicheskiye nauki. 2008. No. 1 (38). pp. 67-69 (In Russian).

12. Kuleshin M.G., Leonova N.A., Nemashkalov P.G. Kontseptualnyye osnovy sotsialnoy otvetstvennosti korporativnykh struktur: istoricheskiy aspekt [Conceptual foundations of social responsibility of corporate structures: the historical aspect]. Science Almanac of Black Sea Region Countries. 2019. No. 1(17). pp. 41-47.

13. Lobeyko Yu.A. Sotsialno-pedagogicheskiy aspekt aktivnosti lichnosti v sisteme obshchestvennogo razvitiya [Socio-pedagogical aspect of personality activity in the system of social development]. Ekonomicheskiye i gumanitarnyye issledovaniya regionov. 2015. No. 1. pp. 15-18 (In Russian).

14. Lobeyko Yu.A. Sotsialnaya aktivnost lichnosti $v$ obshchestve: sotsialnopedagogicheskiye aspekty formirovaniya [Social activity of an individual in society: social and pedagogical aspects of formation]. European Social Science Journal. 2014. No. 7-2(46). pp. 282-284 (In Russian).

15. Matyash T.P., Nesmeyanov Ye.Ye. Pravoslavnyy tip kultury: ideya i realnost [Orthodox type of culture: idea and reality]. Gumanitarnyye i sotsialno-ekonomicheskiye nauki. 2015. No. 3(82). pp. 39-44 (In Russian).

16. Nesmeyanov Ye.Ye. «Tsivilizatsiya molodykh»: ideya i realnost ["Civilization of the Young": Idea and Reality]. Gumanitarnyye i sotsialnyye nauki. 2013. No. 6. pp. 145160 (In Russian).

18 November, 2020 